\title{
Succession of secondary shrubs on Ashe juniper communi- ties after dozing and prescribed burning
}

\author{
G. ALLEN RASMUSSEN AND HENRY A. WRIGHT
}

\section{Abstract}

Secondary brush species (found as minor components of the climax community and those from lower seral stages) have increased after most preseribed burns on the Edwards Plateau of Texas. Originally, most of this area was dominated by Ashe juniper (Juniperus ashei). Line and belt transects were used to estimate brush canopy cover and density on 4 soil series located on 5 topographical positions in untreated, tree dozed, and tree dozed plus prescribed burn areas. Total canopy cover and density were not correlated with time following dozing $(13,16$, or 18 years) or burning $(8,9,10,12,13$, or 14 years). Recovery of brush canopy cover to untreated levels was dependent on the topographical location and treatment. Total brush canopy cover was not different $(P \leq 0.05)$ among untreated, dozed, and dozed plus burned treatments on the Speck soil series occurring on the plateau tops. However, brush canopy cover was reduced by burning on soil series occurring on the sideslopes (Oplin and Brackett variant series) and drainages. Species composition was altered with Ashe juniper being reduced approximately $80 \%$ on dozed plus burned areas. Flameleaf sumac did not occur on untreated areas but comprised an average of $38 \%$ of the woody cover on all burned areas. Other secondary brush species increased, the amount depending on the topographical position. Future management may have to include spot treatment on upland soil series where secondary brush species quickly increase.

Key Words: Juniperus ashei, Rhus lanceolata, Quercus spp., soil series, topography

Prescribed fire is a tool for vegetation manipulation in natural resource management. On rangelands, one of its uses is to manipulate brush communities to increase or maintain site productivity for specific management objectives. In most areas it is used in combination with other brush management techniques (Scifres et al. 1983).

Bray (1904) reported Ashe juniper (Juniperus ashei Buchh.) was originally restricted to shallow ridge sites and escarpments because of its susceptibility to fire which frequently burned on the level areas. Huss (1954) concluded range management practices (e.g., continuous heavy grazing and active fire suppression) have allowed Ashe juniper to spread and increase its dominance to most adjacent sites. As Ashe juniper increased, there was a concommitant decrease in forage production (Rasmussen 1986). Because of Ashe juniper's growth characteristics and its resistance to many range herbicides, the most common practices for its management have been mechanical methods such as tree dozing, chaining, or cabling (Scifres 1980, Vallentine 1971). Wink and Wright (1973) used prescribed fire to reduce woody debris, suppress missed and newly established Ashe juniper plants, and

\footnotetext{
Authors are research assistant and Horn professor, Department of Range and Wildlife Management, Texas Tech University, Lubbock 79409. Senior author's current address is Department of Range Science, Utah State Univeristy, Logan 84321. This manuscript is publication T-9-490 of the College of Agriculture, Texas Tech University.

The authors gratefully acknowledge Robert A. Masters and Guy R. McPherson for their field assistance and Bob Beckham of Spring Gap Ranch for providing the study site.

Manuscript accepted 19 December 1988.
}

enhance forage production following tree dozing.

Effects of prescribed burning on Ashe juniper communities over time have not been determined because of the relatively short period prescribed burning has been used on these communities. Huss (1954) documented the successional trends on areas grazed by goats following wildfires in Real County, Texas, located on the southern Edwards Plateau resource area. However, soil series and topographical positions were not delineated. He found that $R$ hus dominated within 3 years following wildfires and was replaced within 14 years by either a grass or a Quercus community depending on grazing intensity by goats. Information is lacking on longterm successional trends following prescribed burns on Ashe juniper communities, especially as these successional trends relate to soil series. The objective of this study was to determine the influence of tree dozing and tree dozing plus prescribed burning over time on Ashe juniper brush communities in relation to selected soil series and topographical position. Plant names are presented according to Correll and Johnson (1979).

\section{Materials and Methods}

The study area was on Spring Mesa $25 \mathrm{~km}$ southeast of Baird, Texas, in Callahan County. This area is a northern outlier of the Edwards Plateau resource region of Texas, dominated by thin calcareous soils derived from fractured limestone. The mesa has eroded over time leaving 2 benches. One bench is elevated $15-20 \mathrm{~m}$ above the second bench. These upper benches have backslopes and footslopes averaging $20-40 \%$ slope and approximately $100 \mathrm{~m}$ long going down onto the lower bench. The lower bench is 5 to $10 \mathrm{~m}$ above the surrounding sandstone-derived soil, with its backslopes and footslopes having a 10-30\% slope and $25-70 \mathrm{~m}$ long.

In a separate study, soil pits analyzed on Spring Mesa revealed the dominant soil series were associated with topographical position (Rasmussen 1986). The Speck soil series was found on both gently sloping benches. The Oplin and shallow Oplin were located on the backslopes with the Brackett and shallow Brackett on the footslopes. The Mereta and Nuvalde series were on the toeslopes (Birkeland 1984). All soil series were thin to moderately thick 13-18 cm deep, with a parent material of fractured limestone or calcareous shale. Texture ranged from skeletal loam on the Oplin series to clay on the Nuvalde and Mereta soils. Organic matter content was high (3.2\%) in the surface horizon on all soils. Speck series was noncalcareous despite its limestone origin. All other series were calcareous (Rasmussen 1986).

Similar soil series at each topographical position were located in 2 untreated pastures, 3 dozed pastures, and 7 dozed plus prescribed burned pastures. The dozed pastures had been treated 13, 16, and 18 years prior to this study. The burned pastures had been burned $8,9,11,12,13$, and 14 years previous to the initiation of this study. Burns were conducted 4 to 5 years after dozing to remove the downed woody debris and eliminate the missed and recently established juniper plants.

Two to 7 areas were randomly located on each soil in each pasture. Each area was sampled from 4 randomly placed line intercept transects $30 \mathrm{~m}$ long to estimate woody plant canopy 
cover. The line intercept method was used to estimate woody canopy cover because of the rhizomatous nature of several brush species occurring on the area (e.g., white shin oak [Quercus mohriana Buckl.] and flameleaf sumac [Rhus lanceolata Gray, Britt.]). Five quadrats $(1 \times 3 \mathrm{~m})$ were placed on the right side of each line transect at $0,6,12,18$, and $24 \mathrm{~m}$. The number of woody plant stems were counted by species and their average height was measured in each quadrat.

Canopy, stem density, and height of woody species were compared on sites of similar topographical positions using a $t$-test at $P \leq 0.05$ (Steel and Torrie 1980). Linear regression analysis was used to relate age after treatment to woody vegetation on dozed and on dozed plus burned pastures. No differences in woody plant canopy cover, stem density or composition occurred due to length of time after dozing or dozing plus burning, so data were grouped by treatment (dozed, dozed plus burn, and untreated) for subsequent analysis.

Since the number of treated areas were not equal, an unbalanced split-plot design (Steel \& Torrie 1980) was used to analyze the effect of treatment and soil series on the woody plant cover, density, composition, and heights. Treatments (dozed, dozed plus burned, and untreated) were considered main plot effects whereas the topographical positions were considered sub-plot effects. Since treatments were applied to entire pastures, they were considered replications. Sample sites within a pasture were sub-samples. Lines within each sample site were treated as sub-sub-samples. All percentage data were transformed using the square root of the arcsin (Steel and Torrie 1980). The square root transformation was used on density data as suggested by Goodall (1970). Means were separated using Student-Newman-Kuel's range test $(P \leq 0.05)$. Actual means are presented in the tables.

\section{Results and Discussion}

No differences were found in total woody plant cover between soils within a treatment found on the backslopes, footslopes, or toeslopes (data not shown). Species composition followed a similar trend. Since differences did not occur between soils found on similar topographical positions of the backslopes, footslopes, or toeslopes between the benches, they were grouped by topographical position independent of their soils in all subsequent analysis.

Total woody cover and species composition found on the upper and lower benches (Speck soil series) on dozed plus burned areas were significantly different (Table 1). The upper bench supported

Table 1. Percent canopy cover on dozed plus burned areas of all woody species, and the percent composition of Ashe juniper (Juas), shin oak (Qumo), flameleaf sumac (Rhla), and live oak (Qufu) on the Speck soil series found on the upper and lower benches on Spring Mesa near Baird, Texng in 1985.

\begin{tabular}{lcrlrr}
\hline & Total & \multicolumn{4}{c}{ Species } \\
\cline { 3 - 6 } Soil location & canopy cover & Juas & Qumo & Rhla & Qufu \\
\hline Upper bench & $66.8^{*}$ & 4.0 & $73.4^{*}$ & $13.0^{*}$ & 0 \\
Lower bench & $21.4^{*}$ & 16.3 & $17.0^{*}$ & $58.2^{*}$ & 2.4 \\
\hline
\end{tabular}

1* Means within a column are significantly different at $P \leq 0.05$ using a t-test.

$45 \%$ more woody cover than the same soil series on the lower bench. The lower bench was dominated by flameleaf sumac, whereas the upper bench was dominated by white shin oak (Table 1). Total salinity was the only soil constituent (Rasmussen 1986) that was significantly different $(P \leq 0.05)$ with the upper and lower benches averaging $0.22 \mathrm{~kg} / \mathrm{m}^{2}$ and $0.09 \mathrm{~kg} / \mathrm{m}^{2}$, respectively. These levels are not generally considered to be high enough to have an impact on plant species (Brady 1974). Because of differences between the upper and lower benches, they were kept separate in subsequent analysis.

The interaction between the 3 treatments and topographical position on total percent woody cover and percent composition of Ashe juniper were significant $(P \leq 0.05)$ (Table 2). Dozed plus

Table 2. Percent canopy cover of all woody species, and the percent composition Ashe juniper on untreated, dozed, and dozed plus prescribed burned areas on various solls (topographical positions) on Spring Mesa near Baird, Texas 1 in 1985.

\begin{tabular}{|c|c|c|c|c|c|}
\hline \multirow[b]{2}{*}{$\begin{array}{l}\text { Treatment } \\
\text { toeslope }\end{array}$} & \multicolumn{5}{|c|}{ Topographical Position } \\
\hline & $\begin{array}{l}\text { Upper } \\
\text { bench }\end{array}$ & $\begin{array}{l}\text { Lower }^{2} \\
\text { bench }\end{array}$ & Backslope & Footslope & Toeslopes \\
\hline \multirow[t]{2}{*}{$\begin{array}{l}\text { None } \\
\text { Dozed } \\
\text { Dozed+Burned }\end{array}$} & $\begin{array}{l}65 \mathrm{~A} \mathrm{ab} \\
64 \mathrm{~A} \mathrm{a} \\
42 \mathrm{~B} \mathrm{a}\end{array}$ & $\begin{array}{l}\text {-Tota } \\
\text { - } \\
36 \mathrm{~A} \mathrm{~b} \\
29 \mathrm{~A} \mathrm{ab}\end{array}$ & $\begin{array}{l}\text { Canopy C } \\
60 \mathrm{~A} \mathrm{~b} \\
43 \mathrm{~A} \mathrm{ab} \\
27 \mathrm{~B} \mathrm{~b}\end{array}$ & $\begin{array}{l}\text { Oover- } \\
67 \mathrm{~A} \mathrm{ab} \\
34 \mathrm{~B} \mathrm{~b} \\
22 \mathrm{C} \mathrm{b}\end{array}$ & $\begin{array}{r}73 \mathrm{~A} \mathrm{a} \\
17 \mathrm{~B} \mathrm{c} \\
7 \mathrm{~B} \mathrm{c}\end{array}$ \\
\hline & \multicolumn{5}{|c|}{$\begin{array}{l}\text { Percent composition of } \\
\text { Ashe juniper- }\end{array}$} \\
\hline $\begin{array}{l}\text { None } \\
\text { Dozed } \\
\text { Dozed+Burned }\end{array}$ & $\begin{array}{r}65 \mathrm{~A} \mathrm{a} \\
44 \mathrm{~B} \mathrm{~b} \\
8 \mathrm{C} \mathrm{a}\end{array}$ & $\begin{array}{l}52 \overline{\mathrm{A} \mathrm{b}} \\
11 \mathrm{~B} \mathrm{a}\end{array}$ & $\begin{array}{l}81 \mathrm{~A} \mathrm{a} \\
76 \mathrm{~A} \mathrm{a} \\
13 \mathrm{~B} \mathrm{a}\end{array}$ & $\begin{array}{l}90 \mathrm{~A} \mathrm{a} \\
87 \mathrm{~A} \mathrm{a} \\
14 \mathrm{~B} \mathrm{a}\end{array}$ & $\begin{array}{r}74 \mathrm{~A} \mathrm{a} \\
44 \mathrm{~B} \mathrm{~b} \\
8 \mathrm{C} \mathrm{a}\end{array}$ \\
\hline
\end{tabular}

IMeans followed by the same capital letter within a column or means followed by the same small letter within a row in a species are not different according to StudentNewman-Kuel's mean separation test $(P \leq 0.05)$.

${ }_{2}$ No untreated lower bench areas were located in this study.

burned areas had lower total woody cover than dozed only or untreated areas on the upper bench, backslope, and footslope soils. Total woody cover increased on upper bench and backslope soils following dozing or mature juniper to the point where it was not significantly different than untreated areas. This increase on dozed areas is attributed to the rapid growth of white shin oak and Ashe juniper.

Woody plant cover on treated sites was greatest on upper bench soils and lowest on toeslope soils (Table 2). In contrast, on untreated areas, toeslopes had the greatest cover. This reversal of total woody plant cover on toeslope soils (greatest on untreated and lowest on both treatments) is attributed to topographical location. Toeslope soils receive runoff from at least 2 sides. Increased moisture availability on toeslopes probably allows for greater growth of brush species on untreated areas. On treated areas, basal herbaceous plant cover has increased from 1 to $18 \%$ (McPherson and Rasmussen 1989) and seems to be effectively excluding the reestablishment of woody plants.

Ashe juniper was the dominant woody species on untreated and dozed only areas (Table 2). On dozed areas, Ashe juniper comprised almost half of the total brush cover 13 to 18 years after dozing on all soil sites. Even though Ashe juniper was originally removed by the dozing, its composition of the total plant woody cover on backslope and footslope areas increased to levels equal to untreated areas. The seed bank was probably left intact, allowing rapid reestablishment of Ashe juniper. However, on burned areas Ashe juniper averaged less than $14 \%$ of the brush canopy cover. This combination of treatments (dozing followed by fire 4 to 5 years later) effectively removed the mature plants and a majority of the juniper seedlings.

With reduction of Ashe juniper, other brush species increased their dominance, depending on the topographical position (Table 3 ). Although these species differ in percent composition, there was no significant interaction between the soils and treatments. White shin oak was most abundant on the upper bench regardless of treatment (Table 3). Once Ashe juniper was removed, the rhizomatous growth form of white shin oak could quickly take advantage of the decreased competition for space, nutrients, and light. Prescribed burning following dozing did not increase actual percent 
Table 3. Percent composition of white shin oak, flameleaf sumac, and live oak on untreated, dozed, and dozed plus prescribed burned areas on various topographic positions on Spring Meas near Baird, Texas' in 1985.

\begin{tabular}{|c|c|c|c|c|c|c|}
\hline \multirow[b]{2}{*}{ Treatment } & \multicolumn{6}{|c|}{ Topographical Position } \\
\hline & $\begin{array}{l}\text { Upper } \\
\text { bench }\end{array}$ & $\begin{array}{l}\text { Lower } \\
\text { bench }^{2}\end{array}$ & $\begin{array}{l}\text { Back- } \\
\text { slope }\end{array}$ & $\begin{array}{l}\text { Foot- } \\
\text { slope }\end{array}$ & $\begin{array}{l}\text { Toe- } \\
\text { slope }\end{array}$ & Mean \\
\hline & & & -Whit & shin oal & & \\
\hline None & 25 & - & 47 & 0 & 0 & $8 a$ \\
\hline Dozed & 33 & 21 & 17 & 3 & 0 & $10 a$ \\
\hline Dozed+Burned & 47 & 21 & 15 & 10 & 0 & \\
\hline Mean & 32 a & $21 \mathrm{~b}$ & $16 \mathrm{~b}$ & $6 \mathrm{c}$ & $0 \mathrm{c}$ & \\
\hline & & - & $\mathrm{T}^{3}$ & $\begin{array}{l}\text { af sums } \\
0\end{array}$ & 0 & \\
\hline $\begin{array}{l}\text { None } \\
\text { Dozed }\end{array}$ & $\begin{array}{l}0 \\
0\end{array}$ & $\overline{1}$ & $T$ & 2 & 0 & $1 \mathrm{~b}$ \\
\hline Dozed+Burned & 22 & 40 & 51 & 56 & 22 & $39 \mathrm{a}$ \\
\hline Mean & $15 \mathrm{~b}$ & $24 a$ & $28 \mathrm{a}$ & $36 a$ & $13 \mathrm{~b}$ & \\
\hline None & $\mathbf{0}$ & - & 0 & 1 & 4 & $1 \mathrm{a}$ \\
\hline Dozed & $\mathbf{0}$ & 15 & 2 & $\mathbf{T}$ & 27 & $12 \mathrm{a}$ \\
\hline Dozed+Burned & 3 & 13 & 1 & 2 & 20 & $10 \mathrm{a}$ \\
\hline Mean & $1 \mathrm{~b}$ & $14 \mathrm{a}$ & $1 \mathrm{~b}$ & $1 \mathrm{~b}$ & $18 \mathrm{a}$ & \\
\hline
\end{tabular}

Means followed by the same letter in a column or row within a species are not different according to Student-Newman-Kuel's mean separation test $(P \leq 0.05)$.

2No untreated lower bench areas were located in this study.

${ }^{3} \mathrm{~T}=$ trace amounts of brush cover $(<0.5 \%)$.

ground cover of white shin oak over dozed only areas ( 20 and $21 \%$, respectively).

Flameleaf sumac occurred in trace amounts on untreated and dozed only areas. However, flameleaf sumac cover, composition, and density dramatically increased within 8 to 14 years on all burned areas. It was the dominant brush species on the lower bench, backslope and footslope soils (Table 3). The backslopes and footslopes had the lowest water storage capacity resulting from their depth and texture (Rasmussen 1986). In addition, rainfall effectiveness was probably reduced on these steeper slopes. These data suggest flameleaf sumac has the ability to exist on drier sites as well as on the deeper soils (Rasmussen 1986). The fractured limestone on all sites make a precise estimate of available plant water difficult since roots can exploit these fractures. Several authors have suggested that soils on the steeper rock slopes have better moisture relations for plants in semi-arid regions (Fowler and Dunlap 1986, Yair and Danin 1980). They suggest infiltration is enhanced because of less clay, and more fractures are available for plants to exploit. On Spring Mesa, the highly fractured limestone below all soils and the relatively shallow soils $(\leq 50 \mathrm{~cm})$ appear to provide adequate opportunity for plants on the level bench sites to utilize the entire soil profile. The fracturing of the limestone on this mesa also probably allows deep percolation to occur.

The absolute cover of live oak (Quercus fusiformis Small) was not increased by either dozing or burning, though it did not constitute a high percentage of the woody cover composition on lower bench and toeslope soils on both treatments (Table 3). These high levels resulted from the original dozing operation, which left the live oak mottes for shade and wildlife habitat.

Composition of the woody plant cover on toeslope soils on the dozed plus burned areas were co-dominated by flameleaf sumac (22\%), live oak (20\%), and netleaf hackberry (Celtis reticulata Torr.) $(18 \%)$. Only trace levels $(<1 \%)$ of netleaf hackberry occurred on other areas. Water storage capacity was greatest on the toeslope soils (Rasmussen 1986), plus the increased moisture from runoff seems to have allowed herbaceous plants an advantage over the brush species on the toeslopes. Herbaceous basal cover averaged $18 \%$, which was at least $10 \%$ greater than that for all other soils and topographic positions. This increased herbaceous cover may have reduced the establishment of the brush species on both the dozed and dozed plus burned areas.

There was no interaction between treatments and soil sites for total stem, white shin oak, flameleaf sumac, and liveoak stem densities. Because of high variability of stem density found on all sites, neither treatment (dozing or dozing plus burning) significantly decreased the number of woody plant stems (Table 4). Only topographic position had a significant effect $(P \leq 0.05)$ on the total number of stems. The high number of stems found on the benches were white shin oak (68\%).

The number of white shin oak and live oak stems followed similar trends as the total number of stems (data not shown). Flameleaf sumac stems increased $(P \leq 0.05)$ from $0 \%$ on untreated areas to $21 \%$ of the total number of stems on dozed plus burned areas.

The only significant interaction between treatment and topographical position occurred with Ashe juniper stem densities (Table 4). The footslope and toeslope soils had the greatest density of Ashe juniper plants on untreated areas, though 85 and $87 \%$, respectively, were less than $1 \mathrm{~m}$ tall. Backslopes had the highest level of Ashe juniper densities on the dozed only treatments. Ashe juniper densities on dozed plus burned areas (Table 4) responded similarly as its canopy cover (Table 2). Greater than $75 \%$ of Ashe juniper plants found on burned areas were less than $1 \mathrm{~m}$ tall, regardless of soil type or topographical position.

\section{Conclusions}

Succession of woody species following dozing or dozed plus burning depended on the topographical position. Following dozing of Ashe juniper communities on the upper benches and back-

Table 4. Stem densities (No./ha) of all woody species, Ashe juniper, on untreated, dozed, and dozed plus burned areas on various soll series on Spring Mesa near Baird, Texas' in 1985.

\begin{tabular}{|c|c|c|c|c|c|c|}
\hline & \multicolumn{6}{|c|}{ Topographical Position } \\
\hline & Upper bench & Lower bench ${ }^{2}$ & Backslope & Footslope & Toeslope & Mean \\
\hline $\begin{array}{l}\text { None } \\
\text { Dozed } \\
\text { Dozed+Burned }\end{array}$ & $\begin{array}{l}41222 \\
29111 \\
24407 \\
\end{array}$ & $\begin{array}{r}9741 \\
11878 \\
\end{array}$ & $\begin{array}{r}11917 \\
11042 \\
7927 \\
\end{array}$ & $\begin{array}{l}\text { ms (no./ha)- } \\
12000 \\
5809 \\
6875 \\
\end{array}$ & $\begin{array}{l}8250 \\
7111 \\
4282 \\
\end{array}$ & $\begin{array}{r}20889 a \\
10844 a \\
9496 a\end{array}$ \\
\hline Mean & $28711 \mathrm{a}$ & $11076 \mathrm{~b}$ & $8867 b$ & $6875 \mathrm{~b}$ & $5194 b$ & \\
\hline $\begin{array}{l}\text { None } \\
\text { Dozed } \\
\text { Dozed+Burned }\end{array}$ & $\begin{array}{r}2778 \text { A c } \\
1611 \mathrm{~A} \mathrm{~b} \\
74 \mathrm{~B} \mathrm{a}\end{array}$ & $\begin{array}{r}1574 \mathrm{~A} \mathrm{~b} \\
156 \mathrm{~B} \mathrm{a}\end{array}$ & $\begin{array}{r}2500 \mathrm{~A} \mathrm{c} \\
3708 \mathrm{~A} \mathrm{a} \\
340 \mathrm{~B} \mathrm{a}\end{array}$ & $\begin{array}{c}6667 \mathrm{~A} \mathrm{~b} \\
2857 \mathrm{~B} \mathrm{ab} \\
326 \mathrm{C} \mathrm{a}\end{array}$ & $\begin{array}{c}3583 \text { A b } \\
444 \text { B c } \\
734 \text { B a }\end{array}$ & \\
\hline
\end{tabular}

IMeans followed by the same capital letter within a column or means followed by the same small letter within a row in a species are not different according to Student-Newman-Kuel's mean separation test $(P \leq 0.05)$.

2 No untreated lower bench areas were located in this study. 
slopes on Spring Mesa, woody plant cover reached untreated levels within 13 to 18 years. On footslopes and toeslopes total woody cover on dozed only areas is below that found on untreated areas (34\% and $67 \%$ and $73 \%$, respectively). On toeslopes woody cover has remained low $(<17 \%)$. Woody plant cover on the toeslopes was generally restricted to isolated mottes of live oak left from the dozing operation.

Prescribed fire effectively reduced Ashe juniper on all soils in this study. With juniper reduction by prescribed burning, white shin oak or flameleaf sumac became the dominant species depending on topographical location. On the upper benches the Speck soils series had the greatest increase in canopy cover, which is attributed to the abundance of white shin oak.

On burned areas, woody plant cover and species composition responded similarly on the lower benches, backslopes, and footslopes. Total woody cover averaged $26 \%$ and was dominated by flameleaf sumac (48\%). If the management objective for the area is to keep Ashe juniper from dominating the plant community, prescribed fire should be used within the next 5 years since the Ashe juniper plants are approaching $1.3 \mathrm{~m}$ in height. Junipers become concomitantly harder to kill with fire as they get larger (Wink and Wright 1973). Use of prescribed fire would effectively remove the Ashe juniper, but the resprouting nature of the other species may cause more problems.

\section{Literature Cited}

Birkeland, P.W. 1984. Soils and geomorphology. Oxford Univ. Press, N.Y. Bray, W.L. 1904. The timber of the Edwards Plateau of Texas: Its relation to climate, water supply and soil. U.S. Bur. Forest. Bull. 49.

Brady, N.C. 1974. The nature and properties of soils. 8th ed. Macmillan Publ. New York.

Fowler, N.L., and D.W. Dunlap. 1986. Grassland vegetation of the eastern Edwards Plateau. Amer. Midl. Natur. 115:146-155.

Correll, D.S., and M.C. Johnston. 1979. Manual of the vascular plants of Texas. Univ. Texas at Dallas. Richardson.

Goodall, D.W. 1970. Statistical plant ecology. Annu. Rev. of Ecol. and Syst. 1:99-124.

Huss, D.L. 1954. Factors influencing plant succession following fire in Ashe juniper woodland types in Real County, Texas. M.S. Thesis. Texas A\&M Univ. College Station.

MePherson, G.R., and G.A. Rasmussen. 1989. Seasonal herbivory effects on herbaceous plant community patterns. Texas J. Sci. 41:59-70.

Rasmussen, G.A. 1986. Long-term etfects of prescribed burning on Ashe juniper communities. Ph.D. Diss. Texas Tech Univ. Lubbock.

Scifres, C.J. 1980. Brush management: Principles and practices for Texas and the southwest. Texas A\&M Univ. Press. College Station.

Scifres, C.J., J.L. Mutz, G.A. Rasmussen, and R.P. Smith. 1983. Integrated brush management (IBMS): Concepts and case studies with whitebrush and running mesquite. Texas Agr. Exp. Sta. Bull. 1450.

Steel, R.G.D., and J.H. Torrie. 1980. Principles and procedures of statistics. 2nd Ed. McGraw Hill Book Co. New York.

Vallentine, J.F. 1971. Range development and improvements. Brigham Young Univ. Press. Provo.

Wink, R.L., and H.A. Wright. 1973. Effects of fire on an Ashe juniper community. J. Range Manage. 26:326-329.

Yair, A., and A. Danin. 1980. Spatial variation in vegetation as related to soil moisture regime over an arid limestone hillside, and northern Negev, Israel. Oecologia. 47:83-88.

\section{Journal of Production Agriculture}

\section{Cosponsored by the \\ Society of Range Management}

Journal of Production Agriculture offers you the latest production-oriented information from a variety of agricultura! fields. Some of the areas which the journal will report on include: range management, agıonoiny, crop science, soil science, economics, forages, pastures, animal science, weed science, entomology, plant pathology, horticulture and forestry.

Journal of Production Agriculture is published four tumes per year by the American Society of Agronomiy, Crop Science Sucisty of America, and Soil Science Society of America in cooperation with the Socicty of Range Management, American Agricultural Economics Association, American Foraze and Grassland Ccuncil, American Society of Animal Science, and Weed Science Society of America.

Member of SRM or other sponsoring sociecy

United States $\$ 13.00$ Journal of

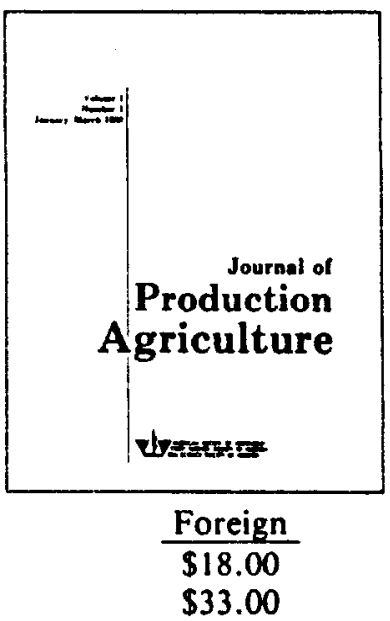
Nonmember $\$ 30.00$

$\$ 33.00$ Check or money order enclosed Bill me

Name

Address

City

State Zip

All payments must bi in U.S. currency. Advance payment and $\$ 3.00$ per subscription (tour issues) is required on all orders outside the United States. Send your order to: 